\title{
How To Measure Student Engagement in the Context of Blended-MOOC
}

\begin{tabular}{|r|l|}
\hline Journal: & Interactive Technology and Smart Education \\
\hline Manuscript ID & ITSE-07-2018-0046 \\
\hline Manuscript Type: & Research Paper \\
\hline Keywords: & MOOC, Student Engagement, blended-MOOC \\
\hline \multicolumn{2}{|c}{} \\
\hline
\end{tabular}

SCHOLARONE

Manuscripts 


\title{
How To Measure Student Engagement in the Context of Blended-MOOC
}

\begin{abstract}
This paper aims to develop a model of measuring student engagement in a blended-MOOC context. Massive Open Online Courses (MOOCs) are those that are delivered, usually by leading universities, with a promise to provide free high-quality education to an unlimited number of learners. They offer an opportunity for 'blended' course design, where instructors can integrate MOOC content within face to face educational activities and components. Three internationally recognized existing frameworks, the National Survey of Student Engagement (NSSE), UK Engagement Survey (UKES) and Student Engagement Questionnaire (SEQ) were combined into a single model. The model was confirmed by a panel of thirty-five expert practitioners. A trial evaluation using the model was carried out on thirteen students who had participated in a course that had adopted a blended-MOOC format. The confirmed model has nine indicators which provide information about distinct aspects of student engagement. It is considered to be the first model designed to measure student engagement within the blended-MOOC context.
\end{abstract}

\section{KEYWORDS}

Blended learning, higher education, student engagement, MOOCs.

\section{INTRODUCTION}

Massive Open Online Courses (MOOCs) are online courses predominantly produced by elite universities with the promise of providing free, high-quality education to an unlimited number of learners (Johnson et al. 2013; UK Universities 2013; Zhang 2013).

A recent development of MOOCs has been the integration of MOOC elements into campus courses in the form of blended learning to make the most of classroom time for activities such as discussions, hands-on activities or working in a group project (Chen 2013). This kind of blended learning has been termed as " distributed flip " (Caulfield et al. 2013), blended / hybrid model (Bruff et al. 2013; Griffiths et al. 2014; Holotescu et al. 2014) or blended MOOCs (LaMartina 2013; Israel 2015). MOOCs themselves have also evolved to blend the use of social networking tools in order to further stimulate engagement and interactions between learners.

The use of MOOC systems in blended contexts has the potential capacity to influence higher education in a variety of ways.

- For students, the systems can influence and shape or structure their approaches to learning and may stimulate class communication;

- For educators, MOOCs may assist the development and selection of online resources and change traditional teaching practices;

- For institutions and researchers, MOOCs can provide large data sets which can be analysed and used to investigate more deeply the processes of learning and learner behaviour.

If MOOC systems are changing teaching practices and campus learning environments, it is reasonable to assume that they are affecting the way students engage with their courses. In spite of this possibility, very little is known about how to measure student engagement in a context where MOOC materials are integrated. This study responds to the need to develop a model that can be used to explore student engagement in higher education within the blended-MOOC contexts.

\subsection{Defining student engagement}

A few decades ago, there was a focus on the concept of student engagement to identify what constitutes an effective learning environment (Coates 2007). A review of the literature on student engagement in higher education has shown that there is a number of student engagement definitions (Barkley 2009). In 1984, Astin 
(1984) defined student engagement as 'the amount of physical and psychological energy that the student devotes to the academic experience'.

Then, Chickering and Gamson published 'The Seven Principles for Good Practice in Undergraduate Education'. These principles are used to improve undergraduate education. Chickering and Gamson found that effective educational practice includes: student-faculty contact; cooperation among students; active learning; prompt feedback; time on task; high expectations; and respect for diverse talents and ways of learning.

In 2000, the National Survey of Student Engagement (NSSE) was developed as a lens to examine the quality of the student learning experience (National Survey of Student Engagement 2007). The NSSE defines student engagement as 'the time and energy students devote to educationally sound activities inside and outside of the classroom, and the policies and practices that institutions use to induce students to take part in these activities' (Kuh 2003). This definition of student engagement is grounded in several decades of prior studies, and specifically in four key research: 'quality of effort' concept (Pace 1984); 'theory of involvement' (Astin 1984); 'seven principles of good practice in undergraduate education' (Chickering \& Gamson 1987) and (Pascarella \& Terenzini 2005) causal model of learning and cognitive development.

From these studies, five benchmarks of effective educational practice have been identified, namely:

1. Active and collaborative learning: this benchmark is designed to measure the extent to which students interact and work with other students, and the extent of student participation in educational purposeful activities inside and outside of the classroom.

2. Student interactions with faculty members: This benchmark is developed to assess student and faculty interaction. This includes participation with teaching staff inside and outside the class, and the level of participation with them in regard to performance, assignments and career plan.

3. Level of academic challenge: This scale focuses on measuring students' academic effort and the institutional expectations of students.

4. Enriching educational experiences: This benchmark is designed to collect information about the number of complementary academic activities available to students. This includes joining in community service, participating in curricular and co-curricular activities.

5. Supportive campus environment: This scale reports the degree to which students perceive their institution is dedicated to student success.

In 2004, Fredricks et al. (2004) further recognised three main dimensions of student engagement. These are detailed as follows:

1. Behavioural engagement: students who are behaviourally engaged would comply with behavioural expectations and norms, such as asking questions in class, attending course-related events etc.

2. Cognitive engagement: students who are cognitively engaged would invest in learning and development, strive to go beyond the basic requirements, and enjoy the academic challenge, such number of assignments emphasizing higher order thinking skills, time spent on coursework requiring reflection, integration and synthesis of concepts, etc.

3. Emotional (affective) engagement: students who are emotionally engaged would experience a range of emotional reactions such as attitude, value, interest, belonging, enjoyment, etc.

\subsection{Student engagement measures}

Student self-reports are the most common method for measuring student engagement. Most of these self-reports are general and not related to specific subjects, although there are some examples of measures that measure student engagement in a specific discipline like math (Kong et al. 2003)) or reading (Wigfield et al. 2008). Some of these reports can be used to measure student engagement at institutional level, while the others are designed for course level. As the aim of this study is to measure student engagement in blended-MOOC courses, the researcher review only self-reports that can be used at course level within higher education institutions.

Measuring student engagement within a particular course experience provides valuable feedback for assessing and improving students' investment in the learning process. The feedback obtained from such an experience could be used as a way of evaluating a particular course's structure, pedagogy and design.

Barkley (2009, p. 44) asserts that, 'whatever means [a] teacher [uses] to [assess] engagement in their classes, gathering appropriate feedback can help close the gap between what teachers think is happening in their classes and what students are actually experiencing.' 
1. The National Survey of Student Engagement (NSSE) is a well-used instrument to study undergraduate student engagement at an institutional level. It was also used by a number of scholars (Robinson \& Hullinger 2008; Delialioğlu 2012; Neumann \& Hood 2009; Owston et al. 2013) to study student engagement at a course-level. The model has ten engagement indicators which grouped into four major themes see table below.

Table 1: NSSE engagement indicators

\begin{tabular}{|c|c|c|}
\hline Theme & Indicators & Description \\
\hline \multirow{4}{*}{ 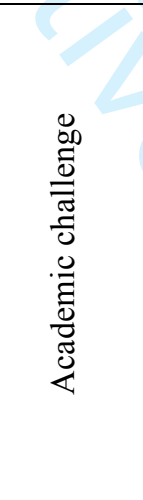 } & $\begin{array}{l}\text { 1) Higher-order } \\
\text { learning }\end{array}$ & $\begin{array}{l}\text { This indicator reflects mental activities such as memorising, } \\
\text { applying, analysing, evaluating and creating new ideas/ ways of } \\
\text { viewing things. }\end{array}$ \\
\hline & $\begin{array}{l}\text { 2) Reflective } \\
\text { integrative } \\
\text { learning }\end{array}$ & $\begin{array}{l}\text { This indicator evaluates the level of making connections among } \\
\text { concepts and between new ideas and previous learning, and } \\
\text { viewing issues from new viewpoints. }\end{array}$ \\
\hline & $\begin{array}{l}\text { Learning } \\
\text { strategies }\end{array}$ & $\begin{array}{l}\text { This indicator assesses the extent to which students use some } \\
\text { effective learning strategies such as identifying key information in } \\
\text { readings, reviewing notes after class, and summarizing course } \\
\text { material. }\end{array}$ \\
\hline & $\begin{array}{l}\text { 4) Quantitative } \\
\text { reasoning }\end{array}$ & $\begin{array}{l}\text { This indicator measures the ability to use and understand } \\
\text { numerical and statistical information in everyday life. }\end{array}$ \\
\hline \multirow{2}{*}{ 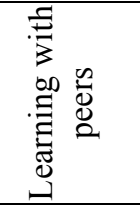 } & $\begin{array}{l}\text { 5) Collaborative } \\
\text { learning }\end{array}$ & $\begin{array}{l}\text { This indicator collects information on how often students engage } \\
\text { in collaborative work and discussions with peers. }\end{array}$ \\
\hline & $\begin{array}{l}\text { 6) Discussions with } \\
\text { diverse others }\end{array}$ & $\begin{array}{l}\text { This indicator examines the extent to which students interact with } \\
\text { and learn from others with different backgrounds and life } \\
\text { experiences. }\end{array}$ \\
\hline \multirow{2}{*}{ 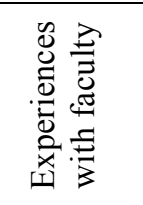 } & $\begin{array}{l}\text { 7) Student-faculty } \\
\text { interaction }\end{array}$ & $\begin{array}{l}\text { This indicator explores how often students work/discuss/interact } \\
\text { with their faculty. }\end{array}$ \\
\hline & $\begin{array}{l}\text { 8) Effective teaching } \\
\text { practices }\end{array}$ & $\begin{array}{l}\text { This indicator captures students' perceptions of how much } \\
\text { teaching staff uses organized instruction, clear explanations, and } \\
\text { effective feedback. }\end{array}$ \\
\hline \multirow{2}{*}{ 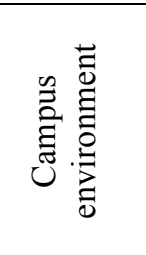 } & $\begin{array}{l}\text { 9) Quality } \\
\text { interactions }\end{array}$ & $\begin{array}{l}\text { This indicator asks students to rate the quality of their interactions } \\
\text { with other students, academic advisors, faculty, student services } \\
\text { staff, and other administrative staff. }\end{array}$ \\
\hline & $\begin{array}{l}\text { 10) Supportive } \\
\text { environment }\end{array}$ & $\begin{array}{l}\text { This Indicator explores students' perceptions of how much an } \\
\text { institution emphasizes services and activities that support } \\
\text { students' learning and development. }\end{array}$ \\
\hline
\end{tabular}

2. The Student Course Engagement Questionnaire (SCEQ) was developed by Handelsman et al. (2005) to measure four types of engagement:

1) Skill engagement includes levels of practicing some learning strategies and skills that promote academic success, such as note-taking. This type corresponds to the NSSE category of level of academic challenge.

2) Emotional engagement includes level of affective involvement with course materials.

3) Participation/interaction engagement includes levels of participation in class and interactions with instructors and other students. This type corresponds to the NSSE category of active and collaborative learning.

4) Performance engagement includes students' levels of performance in the class, such as grades.

3. The Classroom Survey of Student Engagement (CLASSE) is an adaption of NSSE developed by Ouimet \& Smallwood (2005) to assess student perceptions of engagement in a course. CLASSE is composed of two instruments:

1) The student version of CLASSE which asks students how frequently they engage in various educational activities within a particular course.

2) The faculty version of CLASSE which asks faculty of that course how important the various educational activities are in facilitating student success.

The both instruments have six indicators: 1) Engagement Activities, 2) Cognitive Skills, 3) Other Educational Practices, 4) Class Atmosphere Impressions, 5) Optional Course-specific 6) Demographic Items. 
The two versions of CLASSE can be contrasted and examined "to identify important and valued educational practices that are occurring less frequently than desired or expected."1

4. The Student Engagement (SE) is a 14-item assessment which are adapted from the NSSE instrument for use at the course level (Ahlfeldt et al. 2005). The questions examine three aspects of student engagement: 1) Collaborative Learning; 2) Cognitive Development; 3) Personal Skills Development.

5. The UK Engagement Survey (UKES) is an adaption of NSSE to understand UK students' experience in nine key areas:

1) Critical Thinking; which uses the same items of the NSSE Higher order learning indicator.

2) Learning with Others; which asks the same questions of the NSSE collaborative learning indicator.

3) Interacting with Staff; has six questions, some of these questions were taken from the NSSE student-staff interaction indicator.

4) Reflecting and Connecting; which has the same questions of the NSSE reflective \& integrative learning indicator.

5) Course Challenge; includes two items which focus on students' responsibility for their own learning, and their sense of being challenged by the course.

6) Engagement with Research; asks four questions about the emphasis in the course on students learning about the methods and results of research.

7) Staff-Student Partnership; has three questions about the extent students contribute to a joint community of staff and student, and work with teaching staff in improving their course and evaluating teaching and assessment practices.

8) Skills Development (Hard and Soft Skills); involves Twelve questions ask about students' development of a number of skills and abilities.

9) How Students Spend Time; asks seven questions about the number of hours that students spend on different activities.

The UKES can be used at two levels; an institutional level and a course level.

6. The Student Engagement Questionnaire (SEQ) was developed by Coates (2006) to study student engagement in blended course designs and the influence of online learning management systems (LMSs) on students' involvement with their study. The model consists of two parts:

a. General Engagement: General engagement includes nine scales to measure more general forms of campus-based student engagement:

1) Constructive Teaching (CT) scale which is about students' perceptions of whether teachers supported students' active exploration of course materials and construction of knowledge.

2) Supportive Learning Environment (SLE) scale addresses students' perceptions of whether they feel they are members of a supportive community of learners at university.

3) Teacher Approachability (TA) scale measures students' perceptions of teachers' interest in students.

4) Academic Challenge (AC), addresses students' perceptions of whether students feel that feedback and expectations challenge them to learn.

5) Active Learning (AL) scale measures the extent to which students set standards and use practices likely to produce learning.

6) Student and Staff Interaction (SSI) scale measures the level of interaction with teachers.

7) Complementary Activities (CA) scale measures students' involvement in activities around the university campus.

8) Collaborative Work (CW scale) addresses students' participation in a range of collaborative work/activities.

9) Beyond-Class Collaboration (BCC) scale measures the extent to which students are required to and do work together with others outside classroom.

b. Online Engagement: Coates (2006) believes that online learning, which is a part of blended learning, requires its own engagement scales:

1) Online Engagement (OE) scale focuses on the extent to which students incorporate the use of online learning systems into university study.

\footnotetext{
${ }^{1} \mathrm{http}: / /$ nsse.indiana.edu/html/classroom_survey_of_student_engagement.cfm
} 
2) Online Active Learning (OAL) scale is about the degree to which students actively use online learning systems to improve their learning.

3) Online Academic Relevance (OAR) scale measures the extent to which students use online learning systems to contextualise and enhance the relevance of their university study.

4) Online Teaching (OT) scale captures students' perceptions of whether teachers use online learning systems in pedagogically effective ways.

5) Online Collaboration (OC) scale assesses students' use of online systems in collaborative work with peers.

6) Online Social Interaction (OSI) scale is about how students use online learning systems to interact with others.

7) Online Contact with Staff (OCS) scale measures the extent to which students contact with teachers online.

\subsection{Student Engagement within MOOCs}

A number of individuals have made different categorizations and classifications of MOOC learners' engagement patterns. For example:

1. Phil Hill (2013), in the e-literate blog, classified MOOC participants as follows

a) 'Lurkers'- who enrol in the course just to observe or sample a few learning materials at most. Some of them may not even get beyond the registration, so they are basically behind the scenes.

b) 'Passive participants'- who typically watch videos, perhaps take exams, but tend to not participate in the course's activities or discussions.

c) 'Drop-in participants'- who actively participate in specific topics within the course, but do not attempt to finish the course.

d) 'Active participants'- who fully engage in the course and actively participate in course discussions and social tools, and complete the course tasks and activities.

This classification has been also used by Milligan, Littlejohn, \& Margaryan (2013) in their study to describe the engagement patterns in cMOOCs. Stanford University has classified MOOC learners into four classes: 'Auditing, Completing, Disengaging, and Sampling' (Kizilcec et al. 2013). However, these archetypes are dynamic, and participants may change over time from one to the other over the duration of a course (Joseph \& Nath 2013).

2. Hew (2014) selected three top-rated MOOCs in the disciplines of programming languages, literature, and art and design to investigate the factors necessary to promote student engagement in the MOOC context. He found there were five factors behind the popularity of these MOOCs. These include: '(1) problemcentric learning with clear expositions; (2) instructor accessibility and passion; (3) active learning; (4) peer interaction; and (5) using helpful course resources'.

3. Wintrup et al. (2015) explored student engagement in two MOOCs developed by the University of Southampton and delivered through the FuturLearn platform. Wintrup et al. (2015) adapted the UK Engagement Survey (UKES), which is largely derived from NSSE items. The results of the study indicate that 'both MOOCs succeeded in enabling significant proportions of participants to feel engaged in intellectual endeavours such as forming new understandings, making connections with previous knowledge and experience, and exploring knowledge actively, creatively and critically'.

4. Robinson and Hullinger (2008) modified the NSSE survey to assess student engagement within the online learning context. They found that 'online students were modestly engaged in selected NSSE dimensions and had a pattern of engagement that differed from on-campus students' (p. 101).

\section{A BLENDED-MOOC STUDENT ENGAGEMENT (BMSE) MODEL}

Extensive research has been carried out on student engagement in face-to-face courses and online courses. But no single study exists with the aim of developing a model of measuring student engagement in the blendedMOOC context. Most blended learning researches have adapted the NSSE to examine student engagement 
(Laird and Kuh, 2005; Chen, Lambert and Guidry, 2010; Delialioğlu, 2012; Owston, York and Murtha, 2013; Cornelius, Calder and Mtika, 2017). The NSSE instrument is a tool for evaluating general forms of engagement.

The literature review found only one model which was designed for being used in the blended course design. The model was developed by (Coates, 2006) and has nineteen scales for evaluating student engagement when LMSs have been incorporated into on-campus learning (Coates, 2007).

Coates's (2006) model is not applicable for being used in the blended-MOOC context because it is designed to measure the engagement of students in a context where LMSs have been integrated into on-campus study. It asks questions such as how often have you experienced the following:

1. I used an online learning system to contact academic staff.

2. Using learning systems has made me feel like a part of the university.

3. I had individual contact with academic staff online.

The blended-MOOC course design has characteristics and aspects which differ from other course designs. Learning in the blended-MOOC can occur in three main settings: on-campus; on the MOOC platform; or via a social network (see Figure 1).

1. Campus learning: In the blended-MOOC design, students are expected to come to class for more detailed lectures and group discussions. Therefore, they are supposed to engage with their teacher, their peers, and the contents.

2. MOOC Learning: It is assumed that students will watch MOOC videos, take part in some interactive quizzes, read lesson notes, discuss with others, and participate in discussion forums.

3. Social Networking: Students are presumed to reflect and share their learning with other learners via social media.

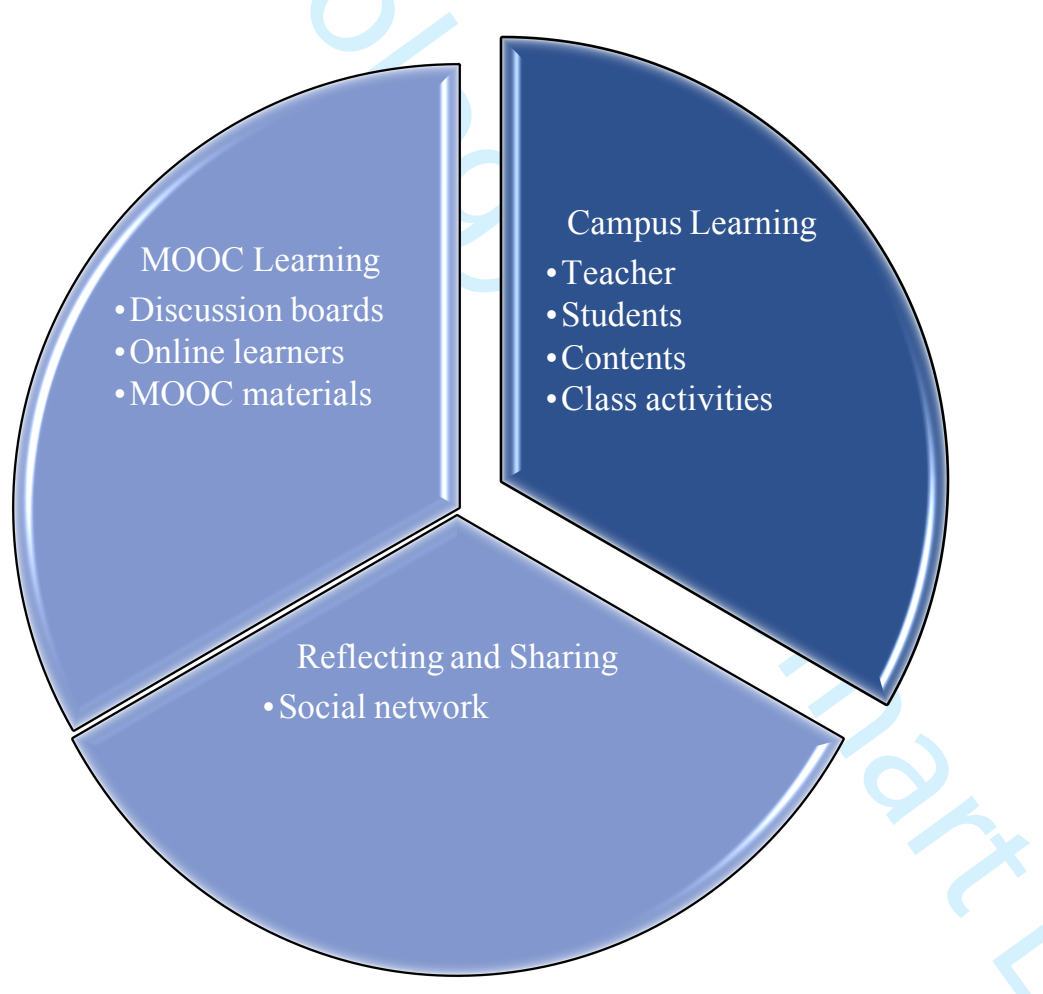

Figure 1: Learning in the blended-MOOC course design

NSSE was selected as this model's theoretical framework along with UKES and SEQ. There is a number of reasons behind the researcher's choosing NSSE:

- NSSE is a large-scale project administered by the University of Indiana that seeks to 'assess the extent to which students engage in educational practices associated with high levels of learning and 
development.' ${ }^{2}$ It is grounded on four main antecedents: "quality of effort" (Pace, 1984); the "theory of involvement" (Astin, 1984); the "seven principles of good practice in undergraduate education" (Chickering and Gamson, 1987) and Pascarella et al.'s (2005) "causal model of learning and cognitive development."

- The NSSE instrument has been used both directly and in a modified form for many different contexts, such as face-to-face, online (Robinson and Hullinger 2008; Wintrup et al. 2015), and blended courses (Laird and Kuh, 2005; Chen, Lambert and Guidry, 2010; Delialioğlu, 2012; Owston, York and Murtha, 2013; Cornelius, Calder and Mtika, 2017).

- The NSSE's items have been adapted internationally with different names, such as: (UKES) in United Kingdom; (AUSSE) in Australia; (SASSE) in South Africa; (ISSE) in Ireland; and (NSSE-China) in China.

- The NSSE publishes engagement data annually, allowing for a comparison with the benchmark score. The NSSE has ten engagement indicators organised under four major themes (see Table 2).

Table 2: NSSE engagement indicators

\begin{tabular}{|c|l|}
\hline Theme & Engagement indicators \\
\hline Academic challenge & $\begin{array}{l}\text { Higher-order learning } \\
\text { Reflective \& integrative learning } \\
\text { Learning strategies } \\
\text { Quantitative reasoning }\end{array}$ \\
\hline Learning with peers & Collaborative learning \\
& Discussions with diverse others \\
\hline Experiences with faculty & Student-faculty interaction \\
& Effective teaching practices \\
\hline Campus environment & Quality of interactions \\
& Supportive environment \\
\hline
\end{tabular}

The current study used only four of the NSSE's indicators; viz.:

1. Higher-order Learning: This indicator captures the extent to which course materials and assessments emphasise challenging mental tasks, such as application, analysis, judgment, and synthesis.

2. Reflective and Integrative Learning: This indicator examines the level of integration of ideas and concepts in the course.

3. Learning Strategies: This indicator asks students how often they applied some effective learning strategies in the course.

4. Collaborative Learning: This indicator gathers information about how often students are involved in collaborative work.

These four indicators are most relevant to the blended-MOOC course design, while the others relate to how students perceive their entire institution, not their experiences with a single course. For example:

- The quality of interactions indicator asks students to rate the quality of their interactions with their academic advisors and/or administrative staff;

- The quantitative reasoning indicator asks students questions, such as:

How often have you used numerical information to examine a real-world problem or issue (unemployment, climate change, public health, etc.);

- The supportive environment indicator captures students' perceptions on how much their institution emphasises the provision of support for their overall well-being, as well as their assisting them to manage their non-academic responsibilities

The current study did not use the student-faculty interaction indicator because the NSSE's items for this indicator overlook the interactions between students and staff which take place inside of the classroom (see Table 3). Nevertheless, this kind of interaction was appreciated by UKES. For example, UKES asked questions such as:

\footnotetext{
${ }^{2} \mathrm{http} / / / \mathrm{nsse}$. indiana.edu/html/survey instruments.cfm
} 
how often have you asked questions in taught sessions or contributed to discussions about course material in other ways?

For this reason, this study has made use of the UKES for the purpose of measuring the interaction between students and faculty.

\begin{tabular}{|c|c|}
\hline \multicolumn{2}{|c|}{ Student-Staff Interaction } \\
\hline NSSE 2015 & UKES 2015 \\
\hline $\begin{array}{l}\text { How often have you: } \\
\text { Talked about career plans with a faculty } \\
\text { member? } \\
\text { Worked with a faculty member on } \\
\text { activities other than coursework? } \\
\text { Discussed course topics, ideas, or } \\
\text { concepts with a faculty member outside of } \\
\text { class? } \\
\text { Discussed your academic performance } \\
\text { with a faculty member? }\end{array}$ & $\begin{array}{l}\text { About how often have you done each of the following } \\
\text { Asked questions in taught sessions or contributed to } \\
\text { discussions about course material in other ways? } \\
\text { Discussed your academic performance and/or } \\
\text { feedback with teaching staff; } \\
\text { Talked about your career plans with teaching staff } \\
\text { or advisors? } \\
\text { Discussed ideas from your course with teaching } \\
\text { staff outside taught sessions, including by email/online? } \\
\text { Worked with teaching staff on activities other than } \\
\text { coursework? } \\
\text { Made significant changes to your work based on } \\
\text { feedback? }\end{array}$ \\
\hline
\end{tabular}

As MOOCs and social media are essential elements of the blended-MOOC design, four online indicators were added to the model to measure the engagement of students with these two components; MOOC and social media. These four indicators were adapted from the SEQ and the NSSE in order to fit into the blended-MOOC teaching method. These indicators are as follows:

- MOOC (online) active learning: Collects information about the degree to which students actively use MOOC systems for enhancing their learning;

- MOOC (online) collaborative learning; Measures the degree to which students use MOOC systems for doing academic work with other online learners;

- MOOC social interaction: Asks about how students use MOOC systems or social networks for the purpose of experiencing a range of interactions and communications with others;

- Teaching with MOOCs: Captures students' perceptions of whether instructors used MOOC elements and materials in pedagogically effective ways.

Thus, as a whole, the proposed model has nine indicators for tracking campus students' engagement with online-related indicators. The details of each indicator are presented in depth in Figure 2 and Table 4. 


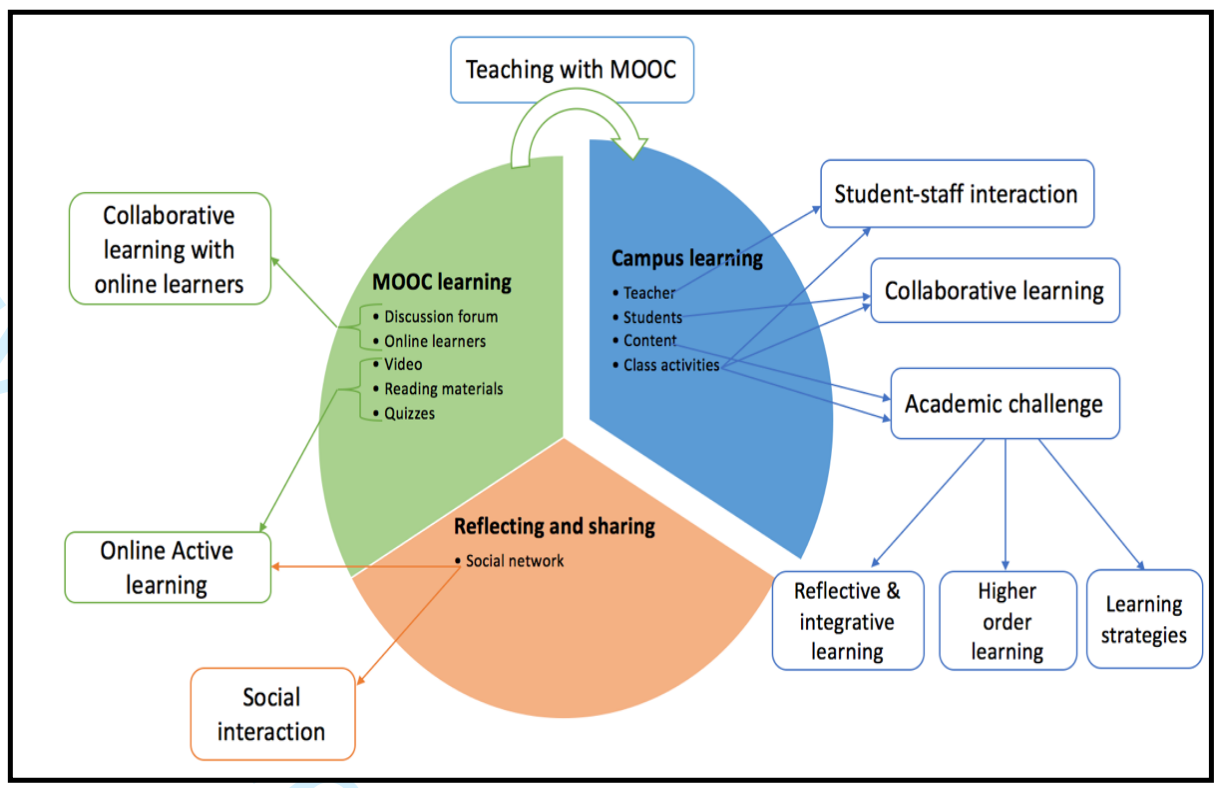

Figure 2: Student engagement in a blended-MOOC setting

Table 4: The Blended-MOOC Student Engagement (BMSE) model

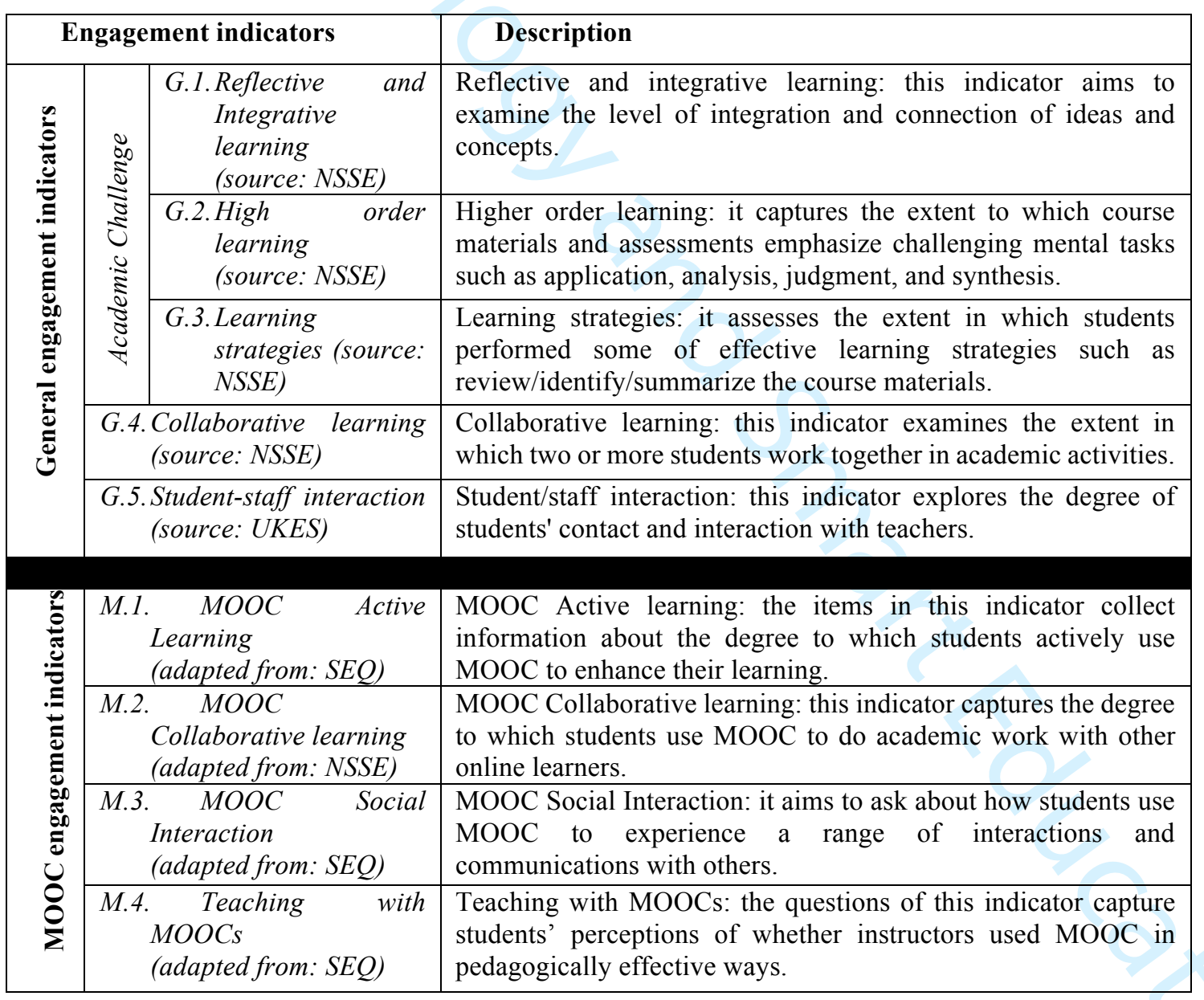




\section{RESEARCH METHODOLOGY}

Two online questionnaires have been used to confirm the model.

1. The expert practitioner questionnaire was designed to collect experts' opinion on each indicator proposed from the literature. The questionnaire was divided into three parts. The first was to gather some general information about the participants. The second part asked nine 5-Likert scale questions, ranging from $($ Very important $=5)$ to $($ Not at all important $=1)$. The last section was two open-ended questions to let participants express themselves and provide information about whether there was uncertainty in any indicator, or whether any further indicators needed to be incorporated. The population of interest were instructors who had an experience in teaching in both settings: on-campus and MOOCs. Also, MOOC facilitators were interested, as facilitators who had experiences in teaching in campus setting and helping MOOC instructors by supporting MOOC learners through MOOC discussion and emails.

2. The student questionnaire was designed after confirming the proposed indicators by the experts. The questionnaire was distributed to and collected from students who had taken a course in a blended-MOOC format to evaluate and test the model.

\subsection{Data analysis method}

The expert questionnaire was analysed by using one-sample t-test to confirm the engagement indicators. If the mean value for a corresponding question of each indicator was significantly greater than 3.5. The reason of comparing with 3.5 is that this number is located between 'neutral' and 'important' on the five-point Likert scale.

\section{Setting hypothesis}

To test the null and alternative hypotheses, a confidence level was set with $95 \%$, and the alpha $\alpha$ with 0.05 . The null and alternative hypothesis were set as:

Null hypothesis: the mean value of the proposed indicator is equal to or lower than 3.5.

Alternative hypothesis: the mean value of the proposed indicator is higher than 3.5 .

The proposed indicator is confirmed when the null hypothesis was rejected; i.e. p-value is less than 0.05 .

\section{RESULTS AND FINDINGS}

The expert questionnaire survey was carried out over two months (from 10 January, 2015 till 15 March, 2015) with an involvement of 35 experts who are academics and educators/facilitators in the MOOC systems. As seen in Figure 3, the participants are from different backgrounds: 31.43\% from Saudi Arabia; $28.57 \%$ of the respondents were from UK; $17.14 \%$ from Malaysia; 5.71\% from Australia; and 2.86\% from each of Algeria, France Mexico, Palestinian, Sweden and the United States.

As displayed in Figure 4, MOOC educators involved in this survey constituted $65.7 \%$ of the respondents, while $31.4 \%$ of respondents were facilitators and others constituted $2.9 \%$. We only accepted academics who taught in the MOOC system. The $2.9 \%$ mentioned earlier were respondents who described themselves as both educators and facilitators. Some $31.4 \%$ of the sample had an experience of more than two years teaching in the MOOC system, and $31.4 \%$ had one to two years' experience and $37.1 \%$ had six months or less (see

Figure 5).

In Table 5, it can be seen that there was an agreement on the importance of all indicators. Interestingly, no participants registered an objection to the importance of any of the following student engagement indicators: reflective and Integrative Learning; higher order learning; student-staff interaction; and MOOC social interaction.

$57.1 \%$ felt that reflective and integrative learning indicator is very important aspect of student engagement in the blended-MOOC context. However, $8.6 \%$ believed MOOC collaborative learning indicator is not important. 


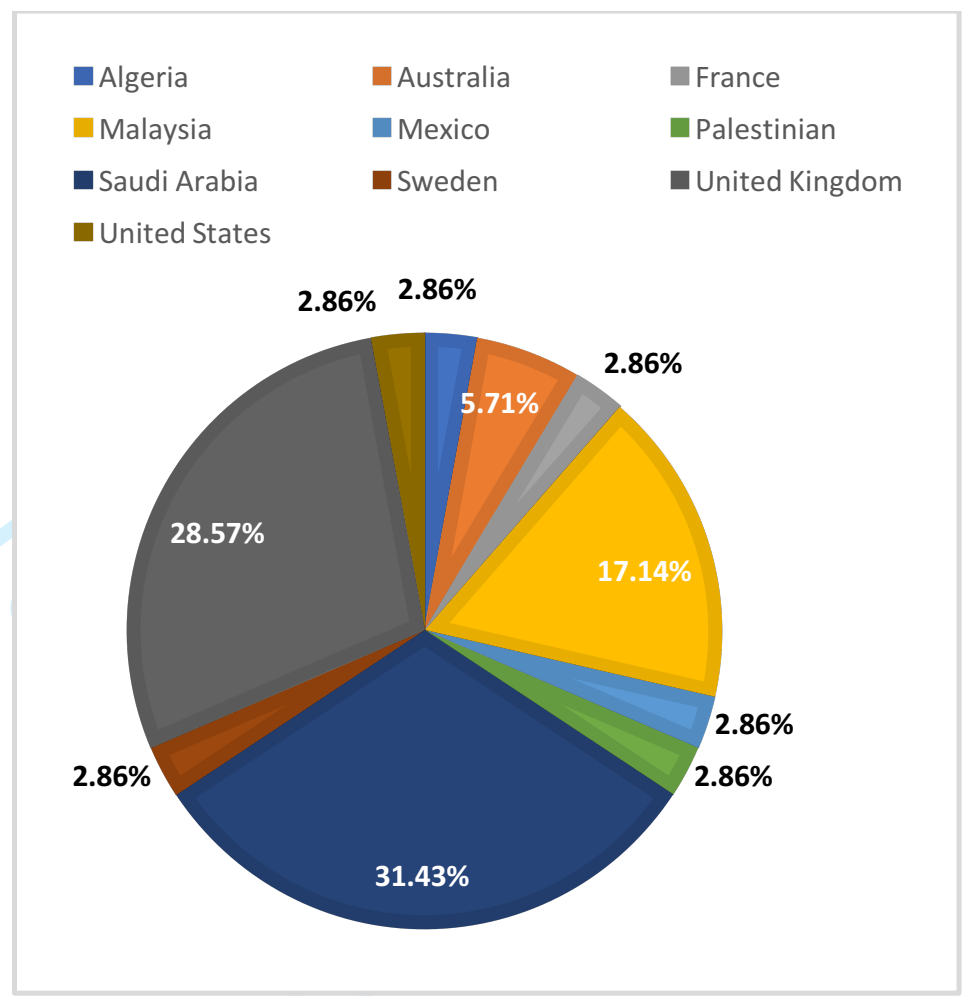

Figure 3: Participants by country

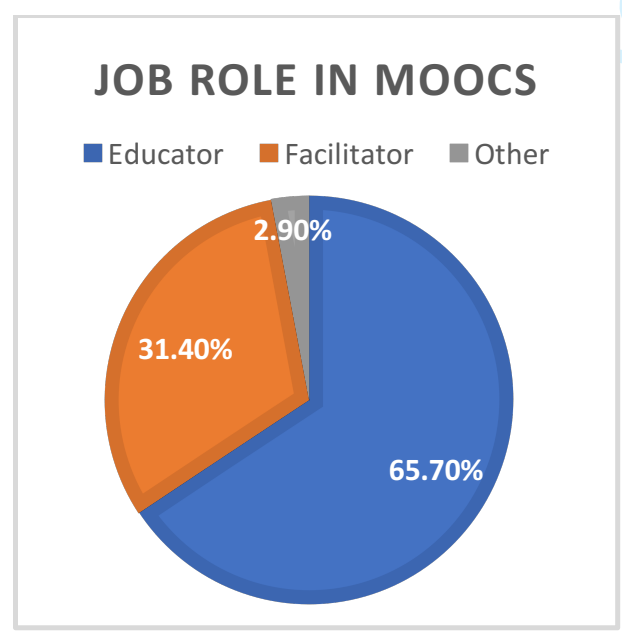

Figure 4: Participants by job role

\section{EXPERIENCE OF TEACHING IN MOOCS}

0-6 months 1-2 years More than 2 years

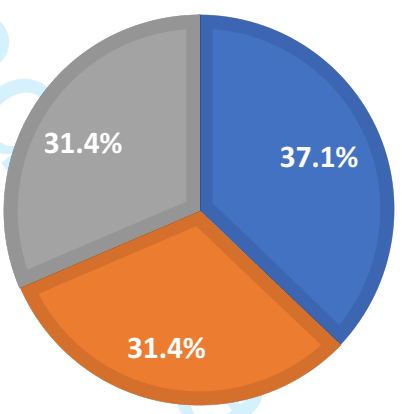

Figure 5: Participants by experience

As shown in Table 5, the analysis of the results shows that all participants agreed on the importance of the proposed scales, as the mean value of each one was higher than the test value (3.5). The fact that all answers were significant, as $\mathrm{p}$ values for all indicators were less than 0.05 , confirms that all proposed indicators were important to the blended MOOC framework.

Table 5: The results of expert questionnaire

\begin{tabular}{|l|c|c|c|c|c|c|}
\hline $\begin{array}{l}\text { Student engagement } \\
\text { indicators }\end{array}$ & $\mathbf{N}$ & Mean & Std. Deviation & $\begin{array}{c}\text { Std. } \\
\text { Error } \\
\text { Mean }\end{array}$ & $\mathbf{t}$ & $\begin{array}{l}\text { Sig. (2- } \\
\text { tailed) }\end{array}$ \\
\hline $\begin{array}{l}\text { Reflective and integrative } \\
\text { learning }\end{array}$ & 35 & 4.57 & 0.502 & 0.085 & 12.62 & $<.05$ \\
\hline
\end{tabular}




\begin{tabular}{|l|c|c|c|c|c|c|}
\hline Higher order learning & 35 & 4.4 & 0.604 & 0.102 & 8.81 & $<.05$ \\
\hline Collaborative learning & 35 & 4.26 & 0.852 & 0.144 & 5.52 & $<.05$ \\
\hline Learning strategies & 35 & 4.23 & 0.69 & 0.117 & 6.25 & $<.05$ \\
\hline Student/staff interaction & 35 & 4.37 & 0.646 & 0.109 & 7.89 & $<.05$ \\
\hline MOOC active learning & 35 & 4.2 & 0.759 & 0.128 & 5.45 & $<.05$ \\
\hline $\begin{array}{l}\text { MOOC collaborative } \\
\text { learning }\end{array}$ & 35 & 3.97 & 0.954 & 0.161 & 2.92 & $<.05$ \\
\hline MOOC social interaction & 35 & 4.2 & 0.719 & 0.122 & 5.75 & $<.05$ \\
\hline Teaching with MOOCs & 35 & 4.11 & 0.758 & 0.128 & 4.79 & $<.05$ \\
\hline
\end{tabular}

\subsection{Pilot study results}

The questionnaire was piloted with and collected from students who had taken either the digital marketing or the web science module in 2015/16 at the University of Southampton. The participants completed questions which were organized into two categories:

- Student engagement questions which were 37 questions classified into nine indicators: reflective and integrative learning; higher-order learning; learning strategies; collaborative learning; studentstaff interaction; MOOC active learning, MOOC collaborative learning, MOOC social interaction; teaching with MOOC.

- One open question asking about their opinions about the questionnaire items/questions and design.

As seen in Table 6, the results comprise Web Science $n=7$ and Digital Marketing $n=6$, in total 13 participants. Another 15 attempted it, but did not complete the questionnaire.

Table 6: Student survey

\begin{tabular}{|l|c|c|c|c|c|}
\hline \multirow{2}{*}{\begin{tabular}{l}
\multirow{2}{*}{ Module } \\
\cline { 3 - 6 }
\end{tabular}} & \multirow{2}{*}{$\mathbf{N}$} & \multicolumn{5}{|c|}{ Time spent in the MOOC } \\
\cline { 3 - 7 } & & none & $\begin{array}{l}\text { about a } \\
\text { quarter }\end{array}$ & $\begin{array}{l}\text { about a } \\
\text { half }\end{array}$ & $\begin{array}{l}\text { all or nearly } \\
\text { all }\end{array}$ \\
\hline Digital marketing & 6 & 0 & 2 & 2 & 2 \\
\hline iPhD Web Science & 7 & 0 & 2 & 2 & 3 \\
\hline Total & 13 & 0 & 4 & 4 & 5 \\
\hline
\end{tabular}

\subsection{Qualitative data from student survey}

Respondents agreed that the items were meaningful and clear. For example, one participant said: "the questions were clear to me. However, it would be more efficient maybe to keep the survey length a bit shorter". Another student stated: "the questionnaire was easy to understand, and the course was really interesting".

Small number of participants made comments on the course design. For example: One said: "The MOOC was not currently active when we were taking the module. We were added once it had finished and so there was little if any current discussions and support etc., in that sense this was one of the major disadvantages, also the MOOC was relied on too much with no real teaching only campus feedback sessions".

Another participant commented: "I used the MOOC purely for educational materials, I was not interested in the social side of it, but that does not detract from my overall impression."

\subsection{Reliability and validity of student questionnaire}

The model was built on three widely used and well-validated models: NSSE, UKES and SEQ. The model has been reviewed by two experts prior to distribution in order to highlight any ambiguous, misleading or wrong questions.

The reliability of the student survey was assessed by considering Cronbach's Alpha. Reliability is generally considered to be satisfactory when values are greater than 0.70 (Hair et al. 2006), but this is sensitive to the number of items in the scale, so for short scales a lower value is acceptable, and conversely for longer scales. 
Table 7 shows that the Cronbach's Alpha value of all apart from in two scales are equal to or more than 0.7. The two scales are slightly below the acceptable level, yet satisfactory for a short scale, thus the constructs were deemed to have adequate reliability.

Table 7: Cronbach's Alpha of each indicator

\section{CONCLUSION}

Upon the review of student engagement literature, the well-established model NSSE was used along with other models UKES and SEQ to build up a model for measuring student engagement in the context of blended MOOC.

In this study, the indicator was accepted if the null hypothesis was rejected. Generally, a p-value is required to be .05 or less in order to reject the null hypothesis. The one-sample t-test (as seen in Table 5) shows that the p-value of all the proposed indicators is less than .05 , so the result was found to be statistically significant and the proposed indicators may be used to measure student engagement in the blended-MOOC setting.

Moreover, the results of the expert questionnaire showed that the experts agreed on the importance of all the proposed indicators in the context of blended MOOC. With regard to the qualitative data, most comments were not indicator-related.

Moreover, the findings of the pilot study confirmed that:

- Questions in the model look clear and meaningful to most students, and

- The survey is deemed to have an adequate reliability in all indicators

\section{REFERENCES}

Ahlfeldt, S., Mehta, S. \& Sellnow, T., 2005. Measurement and analysis of student engagement in university classes where varying levels of PBL methods of instruction are in use. Higher Education Research \& Development, 24(1), pp.5-20.

Astin, A.W., 1984. Student involvement: A developmental theory for higher education. Journal of College Student Personnel, 25(4), pp.297-308.

Barkley, E.F., 2009. Student Engagement Techniques: A Handbook for College Faculty 1st ed., New York, NY: John Wiley \& Sons.

Bruff, D. et al., 2013. Wrapping a MOOC: Student perceptions of an experiment in blended learning. MERLOT Journal of Online Learning and Teaching, 9(2), pp.187-199.

Caulfield, M., Collier, A. \& Halawa, S., 2013. Rethinking online community in MOOCs used for blended learning. Educause Review Online. Available at: https://er.educause.edu/articles/2013/10/rethinking-online-community-inmoocs-used-for-blended-learning [Accessed February 8, 2018].

Chen, J., 2013. Opportunities and challenges of MOOCs: perspectives from Asia, Available at: http://library.ifla.org/157/1/098-chen-en.pdf [Accessed May 24, 2014].

Chickering, A.W. \& Gamson, Z.F., 1987. Seven principles for good practice in undergraduate education. AAHE bulletin, 39 , pp.3-7.

Coates, H., 2007. A model of online and general campus-based student engagement. Assessment \& Evaluation in Higher 
Education, 32(2), pp.121-141.

Coates, H., 2006. Student engagement in campus-based and online education: University connections, London; New York: Routledge.

Delialioğlu, Ö., 2012. Student engagement in blended learning environments with lecture-based and problem-based instructional approaches. Educational Technology and Society, 15(3), pp.310-322.

Fredricks, J.A., Blumenfeld, P.C. \& Paris, A.H., 2004. School engagement: Potential of the concept, state of the evidence. Review of Educational Research, 74(1), pp.59-109.

Freihat, N. \& Zamil, A.I.J. Al, 2014. The effect of integrating MOOC's on Saudi female students' listening achievement. European Scientific Journal (ESJ), 10(34), pp.127-143.

Griffiths, R. et al., 2014. Interactive Online Learning on Campus: Testing MOOCs and Other Platforms in Hybrid Formats in the University System of Maryland, Available at: http://www.sr.ithaka.org/wp-content/mig/reports/SR_Interactive_Online_Learning_Campus_20140710.pdf [Accessed February 2, 2018].

Hair, J. et al., 2006. Multivariate data analysis 6th ed., Harlow, Essex: Pearson.

Handelsman, M.M. et al., 2005. A measure of college student course engagement. The Journal of Educational Research, 98(3), pp.184-192.

Hew, K.F., 2014. Promoting engagement in online courses: What strategies can we learn from three highly rated MOOCS. British Journal of Educational Technology, 47(2), pp.320-341. Available at:

http://www.ifres.ulg.ac.be/MOOC-blog/wp-content/uploads/2016/05/engagement-in-moocs-lu.pdf [Accessed February 1, 2018].

Hill, P., 2013. Emerging student patterns in MOOCs: A (revised) graphical view. E-Literate. Available at: $\mathrm{http}: / /$ mfeldstein.com/emerging-student-patterns-in-moocs-a-revised-graphical-view/ [Accessed April 20, 2014].

Holotescu, C. et al., 2014. Integrating moocs in blended courses. In Proceedings of the International Scientific Conference of eLearning and Software for Education. Bucharest, pp. 243-250.

Israel, M.J., 2015. Effectiveness of integrating MOOCs in traditional classrooms for undergraduate students. The International Review of Research in Open and Distributed Learning, 16(5), pp.102-118.

Johnson, L. et al., 2013. NMC Horizon Report: 2013 Higher Education Edition, Austin, Texas: The New Media Consortium. Available at: https://www.nmc.org/system/files/pubs/1360189731/2013-horizon-report-HE.pdf [Accessed June 11, 2014].

Joseph, A. \& Nath, B., 2013. Integration of Massive Open Online Education (MOOC) system with in-classroom interaction and assessment and accreditation: An extensive report from a pilot study. In Proceedings of the international conference on e-learning, e-business, enterprise information systems, and e-Goverment (IEEE). The Steering Committee of The World Congress in Computer Science, Computer Engineering and Applied Computing (worldComp), p. 105. Available at: http://weblidi.info.unlp.edu.ar/WorldComp2013-Mirror/p2013/EEE3547.pdf [Accessed May 1, 2014].

Kizilcec, R.F., Piech, C. \& Schneider, E., 2013. Deconstructing disengagement: analyzing learner subpopulations in massive open online courses. In Proceedings of the third international conference on learning analytics and knowledge. ACM, pp. 170-179. Available at: http://rene.kizilcec.com/wp-content/uploads/2013/09/Kizilcec-PiechSchneider-2013-Deconstructing-Disengagement-Analyzing-Learner-Subpopulations-in-Massive-Open-OnlineCourses.pdf [Accessed December 4, 2014].

Kong, Q.-P., Wong, N.-Y. \& Lam, C.-C., 2003. Student engagement in mathematics: Development of instrument and validation of construct. Mathematics Education Research Journal, 15(1), pp.4-21.

Kuh, G.D., 2003. What we're learning about student engagement from NSSE: Benchmarks for effective educational practices. Change: The Magazine of Higher Learning, 35(2), pp.24-32. Available at: http://www.tandfonline.com/doi/abs/10.1080/00091380309604090.

LaMartina, D., 2013. Blended MOOCs: The best of both worlds? Campus Technology, 21. Available at: https://campustechnology.com/articles/2013/08/21/blended-moocs-the-best-of-both-worlds.aspx?=CT21.

Milligan, C., Littlejohn, A. \& Margaryan, A., 2013. Patterns of engagement in connectivist MOOCs. MERLOT Journal of Online Learning and Teaching, 9(2), pp.149-159. Available at: https://pdfs.semanticscholar.org/9b8f/37f6573c093b55588185dd1c486fa2465c1b.pdf [Accessed February 2, 2018].

Najafi, H., Evans, R. \& Federico, C., 2014. MOOC integration into secondary school courses. International Review of Research in Open and Distrubuted Learning, 15(5), pp.306-322.

National Survey of Student Engagement, 2007. Experiences that matter: Enhancing student learning and success, Bloomington. Available at: https://files.eric.ed.gov/fulltext/ED512620.pdf [Accessed August 2, 2016].

Neumann, D.L. \& Hood, M., 2009. The effects of using a wiki on student engagement and learning of report writing skills in a university statistics course. Australasian Journal of Educational Technology, 25(3), pp.382-398.

Ouimet, J.A. \& Smallwood, R.A., 2005. Assessment measures: CLASSE - The class-level survey of student engagement. 
Assessment Update, 17(6), pp.13-15.

Owston, R., York, D. \& Murtha, S., 2013. Student perceptions and achievement in a university blended learning strategic initiative. The Internet and Higher Education, 18, pp.38-46. Available at: https://www.sciencedirect.com/science/article/pii/S1096751612000863 [Accessed February 13, 2018].

Pace, C.R., 1984. Measuring the quality of college student experiences: An account of the development and use of the college student experiences questionnaire, Los Angeles, CA: Higher Education Research Ins. Available at: https://files.eric.ed.gov/fulltext/ED255099.pdf [Accessed February 1, 2018].

Pascarella, E.T. \& Terenzini, P.T., 2005. How college affects students: A third decade of research, San Francisco, CA: John Wiley \& Sons.

Pérez-Sanagustín, M. et al., 2016. Does taking a MOOC as a complement for remedial courses have an effect on my learning outcomes? A pilot study on calculus. In European Conference on Technology Enhanced Learning, ECTEL 2016, Lyon, France, September 13-16, 2016, Proceedings. Springer, Cham, pp. 221-233.

Robinson, C.C. \& Hullinger, H., 2008. New benchmarks in higher education: Student engagement in online learning. Journal of Education for Business, 84(2), pp.101-109.

UK Universities, 2013. Massive open online courses (MOOCs) Higher dducation's digital moment?, London, UK. Available at: http://www.universitiesuk.ac.uk/policy-and-analysis/reports/Documents/2013/massive-open-onlinecourses.pdf [Accessed August 5, 2017].

Wigfield, A. et al., 2008. Role of reading engagement in mediating effects of reading comprehension instruction on reading outcomes. Psychology in the Schools, 45(5), pp.432-445.

Wintrup, J., Wakefield, K. \& Davis, H., 2015. Engaged learning in MOOCs: a study using the UK Engagement Survey, Available at: https://www.heacademy.ac.uk/node/10346 [Accessed January 29, 2015].

Zhang, Y., 2013. Benefiting from MOOC. In A Paper presented in EdMedia: World Conference on Educational Media and Technology. Association for the Advancement of Computing in Education (AACE), pp. 1372-1377. 